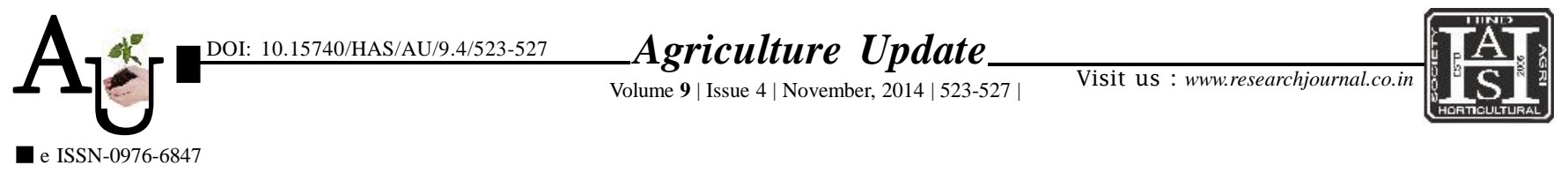

\title{
Research Article Constraints faced by soybean growers in recommended seed production technology
}

Article Chronicle :

Received :

04.09.2014;

Revised :

22.09.2014;

Accepted :

01.10.2014

KeY WoRds:

Constraints,

Soybean growers,

Seed production

technology

\section{P.B. SHINDE, P.R. DESHMUKH AND R.D. AHIRE}

SUMMARY : The present study was conducted in Parbhani district of the Marathwada Region of Maharashtra state. Three talukas were selected randomly. From each taluka four villages were selected on the basis of list of the soybean seed growers in Parbhani district obtained from Mahabeej Office Parbhani. Thus, 12 villages were selected for present study. Ten soybean seed production growers from each village were selected randomly thus, 120 respondents were selected by following lottery method from selected villages. They were interviewed, personally to collect the data with the help of structured interview schedule. The collected data were processed and statistically analyzed.

How to cite this article : Shinde, P.B., Deshmukh, P.R. and Ahire, R.D. (2014). Constraints faced by soybean growers in recommended seed production technology. Agric. Update, 9(4): 523-527.

Author for correspondence :

\section{P.B. SHINDE}

Department of Extension Education, College of Agriculture, Vasantrao Naik

Marathwada Krishi

Vidyapeeth, PARBHANI

(M.S.) INDIA

Email: priyankashinde $1311 @$ gmail.com

See end of the article for authors' affiliations 